\title{
Relação entre a condutividade térmica e parâmetros físicos dos gnaisses Casablanca, Juparaná Delicato e Giallo Falésia (Ceará-Brasil)
}

\author{
Maria Angélica Batista Lima', Antônio Carlos Artur', José de Araújo Nogueira Neto \\ Edgar Romeo H. Figueiredo ${ }^{4} \&$ Antônio C. Galindo ${ }^{5}$
}

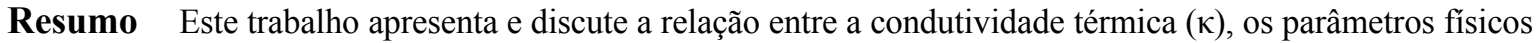
e os aspectos petrográficos dos gnaisses Casablanca, Delicato e Falésia. De maneira geral, os resultados de condutividade térmica, apesar de sofrerem influências locais de mineralogia, refletem as características físicas gerais de cada litotipo. Neste caso, as características físicas discrepantes influenciam de forma significativa os resultados inclusive os de condutividade térmica. Verifica-se que os valores mais baixos de condutividade térmica $(\kappa)$ do gnaisse Falésia são compatíveis com os resultados de seus índices físicos, uma vez que a condutividade será tanto menor quanto maior for a porosidade da rocha ou quanto mais baixa for sua massa específica. O Delicato apresenta valores mais altos de velocidade de ultra-sons ao natural, denotando uma maior coesão desta rocha em relação às demais estudadas. Os menores valores foram determinados no Falésia e são controlados por níveis micáceos, microfissuras e intensidade de alteração nos feldspatos. O Falésia apresentou os maiores valores de dilatação térmica favorecidos pela quantidade expressiva de biotita e pela susceptibilidade deste mineral à fadiga térmica. As três amostras se comportam como rochas de média a alta condutividade térmica com valores médios de $3,19 \mathrm{~W} / \mathrm{m}^{\circ} \mathrm{K}$ para o Casablanca e $3,64 \mathrm{~W} / \mathrm{m}^{\circ} \mathrm{K}$ para o Delicato. O Falésia apresenta o menor valor médio $\left(2,99 \mathrm{~W} / \mathrm{m}^{\circ} \mathrm{K}\right)$, creditado à ocorrência de microfissuras e maior intensidade de alteração dos minerais desta rocha. Fica evidente que os resultados de condutividade térmica ratificam e respondem de forma coerente aos ensaios e resultados físicos e tecnológicos servindo como mais uma ferramenta na caracterização petrofísica das rochas.
\end{abstract}

Palavras-chave: Rochas de revestimento, Condutividade térmica, Parâmetros físicos.

\begin{abstract}
Relationship between thermal conductivity and physical parameters of gneisses Casablanca, Juparaná Delicato and Giallo Falésia (Ceará-Brazil). This work presents and discusses the relationship among the thermal conductivity $(\kappa)$, the physical parameters and the petrographic aspects of the Casablanca, Delicato and Falésia gneisses. In general, the outcomes of thermal conductivity, although affected by local influences from the mineralogy, they reflect the general physical characteristics of each different rock. In this case, the discrepant physical characteristics influence significantly the results, including the thermal conductivity. The results show that the lower values of thermical conductivity $(\kappa)$ from the Falésia gneiss are compatible with the results of its physical índex, since the level of conductivity will be inverse to the rock porosity level (high conductivity, low rock porosity), or direct to the specific mass (low conductivity, low specific mass). The Delicato gneiss presents higher values of ultrasonic speed on its natural state, denoting a higher cohesion of this rock in comparison to the others. The lower values were stated to the Falesia gneiss, and are controlled by the micaceous levels, fissures and change intensity in the feldspars. The Falesia gneiss showed the higher values of thermical dilatation, improved by the expressive amount of biotite and by the susceptibility of this mineral to thermal fatigue. The three samples have a behavior similar to that of rocks of medium to high thermal conductivity, with mean values ranging from $3,19 \mathrm{~W} / \mathrm{m}^{\circ} \mathrm{K}$ (Casablanca gneiss) to $3,64 \mathrm{~W} / \mathrm{m}^{\circ} \mathrm{K}$ (Delicato gneiss). The Falesia gneiss shows the lower mean value $\left(2,99 \mathrm{~W} / \mathrm{m}^{\circ} \mathrm{K}\right)$, as consequence of the presence of fissures and higher intensity of mineral alteration. Conclusively, the results of thermal conductivity ratify and answer in a consistent way the tests and physical and technological results serving as a tool to petrophysical characterization.
\end{abstract}

Keywords: Dimension stones, Thermal conductivity, Physical Parameter.

INTRODUÇÃO A condutividade térmica das rochas é um tema relativamente complexo, uma vez que depende de vários fatores e, dentre estes, merecem destaque a mineralogia, composição química, porosidade, tipo de fluido no espaço poroso, densidade, pressão, temperatura, textura, estrutura, grau de consolidação, grau de alteração etc. Sabe-se que uma rocha é constituída por um agregado de minerais, cada um com valores

1,2 - UNESP - Universidade Estadual Paulista/IGCE, Programa de Pós-Graduação em Geociências, Departamento de Geologia Aplicada, Instituto de Geologia e Ciências Exatas-IGCE, Rio Claro (SP), Brasil. E-mails: angelicabt_br@yahoo.com.br, acartur@rc.unesp.br 3 - UFC - Universidade Federal do Ceará/DEGEO, Departamento de Geologia-DEGEO, Fortaleza, CE, Brasil. E-mail: nogueira@ufc.br 4,5 - UFRN - Universidade Federal do Rio Grande do Norte/DEGEO, Departamento de Geologia, PPGG-UFRN, Natal (RN), Brasil. E-mails: romeoufrn@hotmail.com, galindo@geologia.ufrn.br 
característicos (ou intervalo) de condutividade térmica, portanto, é de se esperar que, ao variar as proporções entre os minerais ou a orientação dos cristais, mesmo que minimamente, a condutividade térmica também sofra modificações, mostrando uma complexa interação de variáveis, exigindo, para tanto, não só o estudo de tais propriedades, mas também o entendimento das leis que regem a termodinâmica.

Quando o tema é parâmetro térmico, a literatura especializada contribui muito pouco em termos qualitativos, principalmente quando se trata de "rochas", pois quase sempre os minerais são privilegiados, em todos os casos, fornecendo apenas dados quantitativos. A idéia é correlacionar parâmetros quantitativos (dados numéricos) avaliados a partir de placas polidas ou amostras in natura com os qualitativos (textura, mineralogia, porosidade etc.), avaliados em seções delgadas de rochas utilizadas com fins ornamentais.

OBJETIVOS Este trabalho tem como principal objetivo comparar os resultados de condutividade térmica de 3 litotipos de composições mineralógicas relativamente similares e seus respectivos ensaios tecnológicos, correlacionando os valores de condutividade térmica com suas respectivas variáveis físicas.

Trata-se de um importante segmento de uma tese de doutorado na qual foi abordada a alteração das rochas de revestimento em orla marítima, a partir da análise qualitativa da alterabilidade destas rochas, submetidas a condições climáticas e intempéricas, em laboratório, que simulam as condições vigentes no litoral.

MATERIAIS E MÉTODOS Esta etapa foi desenvolvida, em sua maior parte, nos laboratórios da Fundação Núcleo de Tecnologia Industrial-NUTEC onde se encontram as câmaras climáticas e os equipamentos utilizados na preparação dos corpos-de-prova e na execução dos ensaios tecnológicos de controle. Já os ensaios de condutividade térmica foram realizados nas dependências do Laboratório de Condutividade Térmica da Universidade Federal do Rio Grande do Norte (UFRN).

Dentre os ensaios realizados destacam-se: análise petrográfica, índices físicos, resistência à compressão uniaxial simples, aptidão de molhagem, velocidade de propagação de ondas ultra-sônicas longitudinais, dilatação térmica linear e condutividade térmica.

Análise petrográfica As análises petrográficas foram realizadas nos três tipos comerciais estudados, levando em consideração as determinações gerais das Normas NBR -12768 (ABNT) e C-294-86 (ASTM), bem como as orientações presentes em Navarro (1998), Rodrigues et al. $(1996,1997)$ e Artur et al. (2001). A análise das características microscópicas seguiu a metodologia tradicional, sendo obtida em microscópio petrográfico (Laborlux 12pol.). Foram avaliados a disposição e o comportamento mineralógico, bem como o tipo e a distribuição por $\mathrm{mm}^{2}$ dos contatos minerais e microfraturamentos.

Índices físicos $\mathrm{O}$ procedimento laboratorial para de- terminação dos índices físicos seguiu a norma NBR 12.766 da ABNT (1992b) sendo ensaiados 10 (dez) corpos-de-prova de cada um dos litotipos estudados, totalizando assim trinta corpos-de-prova. Os corposde-prova com dimensões de $5 \mathrm{~cm}$ x $5 \mathrm{~cm}$ x $5 \mathrm{~cm}$ foram inicialmente secos em estufa por 24 horas (massa seca) e posteriormente imersos em água durante 24 horas, sendo procedida à pesagem para o cálculo da massa saturada e submersa. Ao final do ensaio foram obtidos os seguintes parâmetros: massa específica aparente seca $\left(\mathrm{kg} / \mathrm{m}^{3}\right)$, massa específica aparente saturada $\left(\mathrm{Kg} / \mathrm{m}^{3}\right)$, porosidade aparente (\%) e absorção d'água aparente.

Resistência à compressão uniaxial simples Esta determinação foi realizada segundo a norma NBR 12.767 (ABNT 1992c) em 7 (sete) corpos-de-prova para cada uma das três amostras, totalizando 21 (vinte e um) corpos-de-prova ao natural. Foi utilizada uma prensa com capacidade de 200t da marca EMIC, sendo a tensão de ruptura determinada perpendicularmente à direção de estruturação da rocha.

Velocidade de propagação de ondas ultra-sônicas longitudinais A determinação da velocidade de propagação de ondas, baseada na norma ASTM D 2845 (ASTM 2000), foi efetuada em todos os corpos-de-prova destinados ao ensaio de compressão. A medição foi realizada utilizando-se o Portable Ultrasonic Non-Destructive Digital Indicating Test-PUNDIT, sendo avaliada a velocidade de propagação em 3 (três) direções assim distribuídas: duas no plano de foliação e uma ortogonal a este (X,Y e Z).

Dilatação térmica linear Os dados de dilatação térmica linear foram obtidos no laboratório de Rochas Ornamentais da UNESP, por meio do dilatômetro marca CONTENCO projetado para baixar e elevar a temperatura, numa taxa de $0,3^{\circ} \mathrm{C} / \mathrm{min}$, até os limites de $0^{\circ} \mathrm{C}$ e $50^{\circ} \mathrm{C}$, respectivamente. Este ensaio seguiu as diretrizes da norma NBR 12.765 (ABNT 1992e) e constou de medições em doze cilindros dos três litotipos estudados, sendo seis cilindros paralelos e seis perpendiculares à direção do plano de foliação da rocha. A amostragem foi, ainda, composta da rocha no seu estado natural e após exposição em câmara salina, com o objetivo de averiguar se existe ou não influência da atmosfera marinha na dilatação das rochas.

Aptidão de molhagem Para a determinação desta característica da superfície da rocha, foi utilizado o ensaio de determinação do tempo de absorção de microgotas. A determinação da aptidão de molhagem fornece indicações sobre o estado da superfície da rocha permitindo detectar a presença de heterogeneidades (Ferreira Pinto 1994 in Rodrigues 1998). O Procedimento de ensaio foi baseado na metodologia adotada por Rodrigues (op cit) e constou do ensaio em três placas de $10 \mathrm{~cm}$ x $10 \mathrm{~cm} \times 2 \mathrm{~cm}$ de rochas polidas, secas durante $72 \mathrm{~h}$ a uma temperatura de $60 \pm 5^{\circ} \mathrm{C}$. Depois de esfriarem por $24 \mathrm{~h}$ num dissecador, as placas foram dispostas numa 
superfície horizontal e, utilizando-se a água destilada contida numa pipeta deixa-se cair sobre a superfície da placa, uma microgota com $4 \pm 0,4 \mu 1$. Deve-se manter a pipeta afastada cerca de $10 \mathrm{~mm}$ da superfície de ensaio. O tempo de absorção total da microgota é o intervalo determinado entre o instante em que esta toca a placa de rocha até desaparecer da superfície. Este mesmo processo é efetuado sobre uma placa de vidro fosco que permite determinar o tempo médio necessário à evaporação total das microgotas. O tempo de absorção de microgotas é expresso em \%, sendo obtido por meio da seguinte expressão (equação 1):

$$
T p=\left[\frac{\sum_{i=1}^{n}\left[\frac{t i}{t v}\right]}{n} \times 100\right]
$$

onde tp é o tempo de absorção das microgotas, ti é o tempo necessário à absorção das microgotas na placa, $t v$ é o tempo médio necessário à evaporação total das microgotas na superfície do vidro polido e $n$ é o número de microgotas utilizadas na realização do ensaio.

Condutividade térmica Para os procedimentos de medição foram selecionadas 3 amostras polidas dos gnaisses Casablanca, Juparaná Delicato e Giallo Fa-

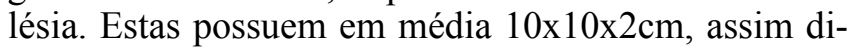
mensionadas de forma a permitir pelo menos 4 medidas em locais distintos, como mostrado na figura 1. Este conjunto de amostras possui espessura dentro das dimensões mínimas sugeridas pelo fabricante.

O passo inicial foi demarcar arbitrariamente o vértice mestre, ponto de partida para determinação dos demais parâmetros. Como mostrado na figura 2, o posicionamento do vértice é fixo e localizado na porção su-
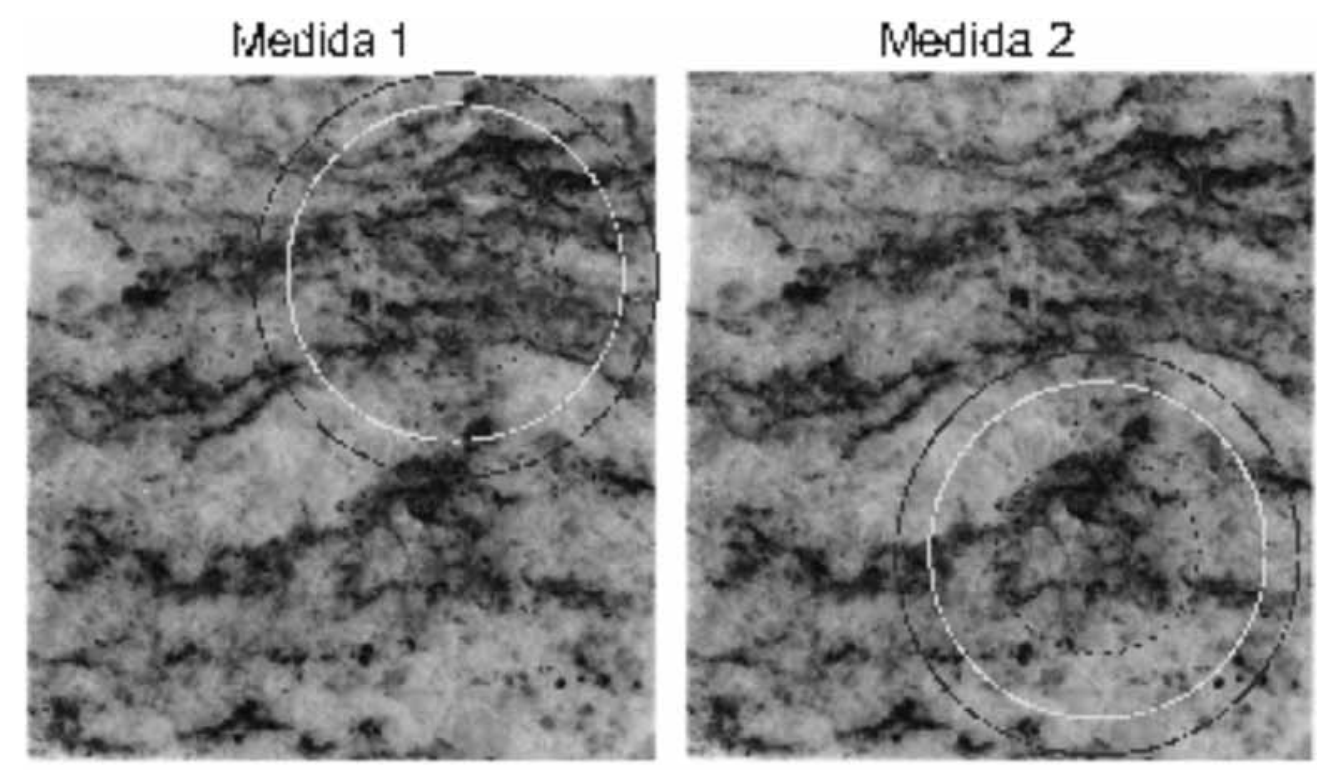

Medida 3

Medida 4
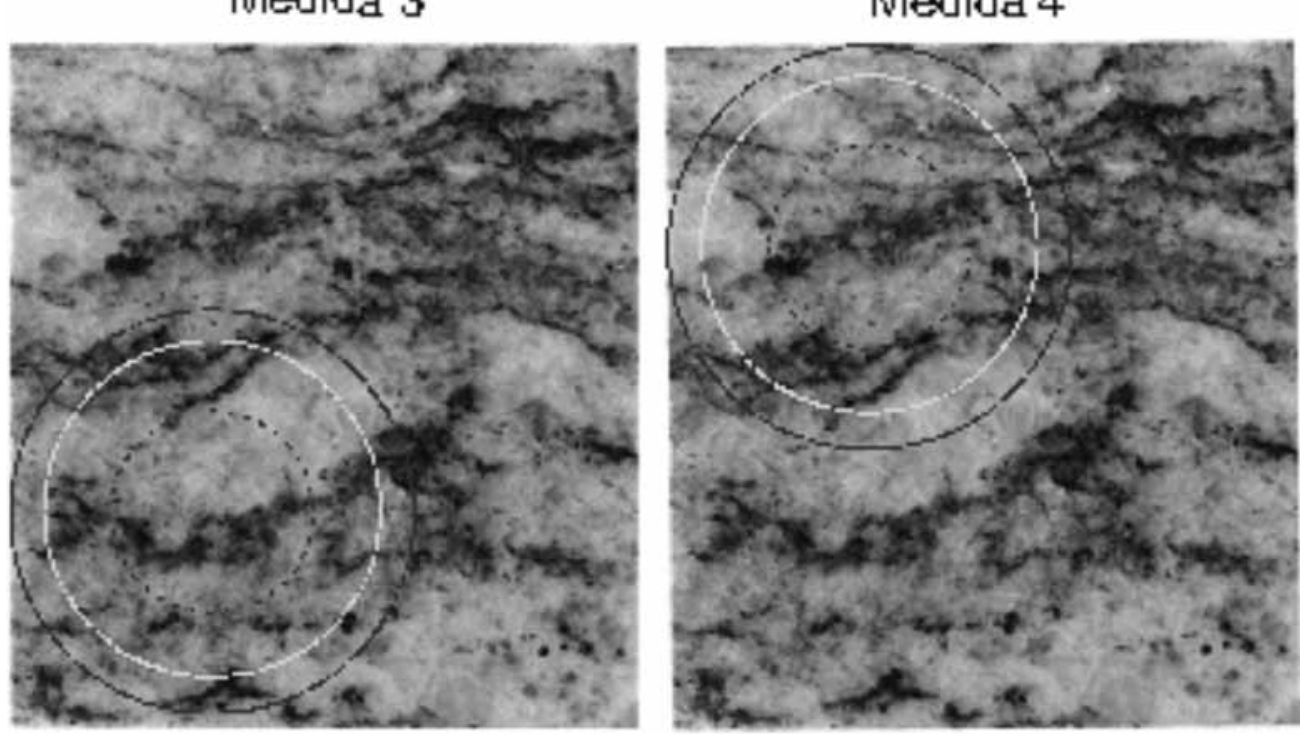

Figura 1 - Placas do gnaisse Casablanca com as respectivas demarcações dos pontos de leitura. 


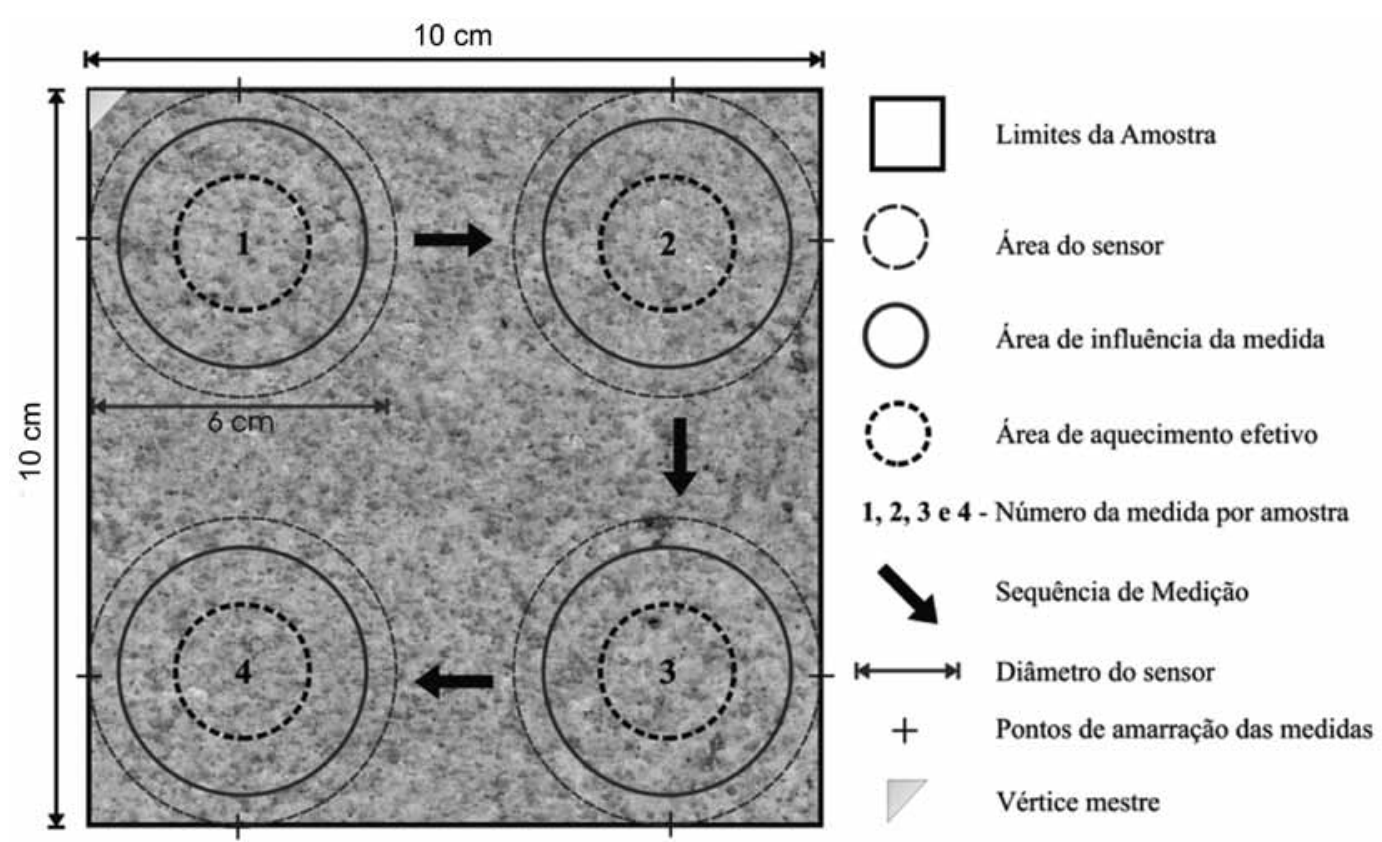

Figura 2 - Procedimento de aquisição dos dados de condutividade térmica.

perior esquerda da amostra. A partir desse vértice foram determinadas as 4 regiões onde seriam realizadas as medidas, sendo estas auxiliadas pelos pontos de amarração (tangente às bordas da amostra), totalizando assim 8 pontos, sendo dois por medida. O procedimento de aquisição dos dados foi realizado no sentido horário e repetido em todas as amostras, de forma que foi possível realizar novas medidas para controle e/ou verificação dos resultados e, de maneira especial, avaliar as variáveis (fase mineral, fissuramentos, etc.) que mais influenciaram nos resultados. Este ensaio possui a vantagem de não alterar as características físico-químicas das amostras, sendo, portanto, um método não destrutivo.

CONDUTIVIDADE TÉRMICA A condutividade térmica de um mineral é a habilidade deste em conduzir calor. Ela é uma propriedade vetorial e depende da composição e estrutura interna do cristal (Dana 1969). Todos os sistemas cristalográficos, exceto o sistema cúbico, são anisotrópicos, ou seja: o calor propaga-se diferentemente nas diversas direções. Em outras palavras, quanto maior o valor da condutividade térmica de um mineral, maior será sua habilidade em conduzir calor e esta propriedade será sempre relacionada às suas características físicas, químicas e cristalográficas.

A condutividade térmica dos minerais é muito melhor definida e estudada se comparada com a das rochas, pois as características físicas, químicas e cristalográficas são geralmente melhor controladas. Contudo, quando se trata de minerais, segundo Clauser \& Hueges (1995), os principais problemas na aquisição dos dados de condutividade térmica são a pureza e o tamanho das amostras. Por sua vez, a condutividade térmica em rochas dependerá de fatores tais como textura, estrutura $\mathrm{e}$ anisotropias (foliação, lineação, etc.). Estes fatores são complexos e sofrem variações significativas dependendo da direção de medição.

Em termos gerais é possível demonstrar que, assim como outros parâmetros físicos, a relação das variáveis térmicas dependerá fundamentalmente das características físicas, mecânicas e químicas da rocha e estas características estarão intimamente relacionadas à estrutura, textura e composição mineralógica da mesma (Fig. 3, Navarro 2002).

PETROGRAFIA As rochas objetos desta pesquisa apresentam padrões texturais movimentados e variações cromáticas entre tons de róseo, cinza esbranquiçado e branco amarelado, que favoreceram a sua utilização como rocha ornamental tendo sido rápida e amplamente reconhecidas pela indústria.

A associação mineral nestes gnaisses de composição granítica é formada essencialmente por feldspato potássico (microclínio), quartzo, plagioclásio (albita com porções mais cálcicas no centro), biotita, muscovita e granada e, como produtos de alteração, são encontrados sericita, epidoto, clorita, muscovita, argilo-minerais, óxidos e hidróxidos de ferro. Os acessórios estão representados por opacos e raros cristais de zircão e apatita.

Os litotipos estudados são aqui classificados petrograficamente como granada-biotita-muscovita gnaisse (Casablanca) e granada-muscovita-biotita gnaisse (Juparaná Delicato e Giallo Falésia). No entanto, apesar das similaridades observadas à luz do microscópio petrográfico, os três tipos são diferenciados entre si por mudanças na textura e coloração, sendo denominados comercialmente como "Casablanca", o de cor branca com tons de cinza médio, "Giallo Falésia“, 


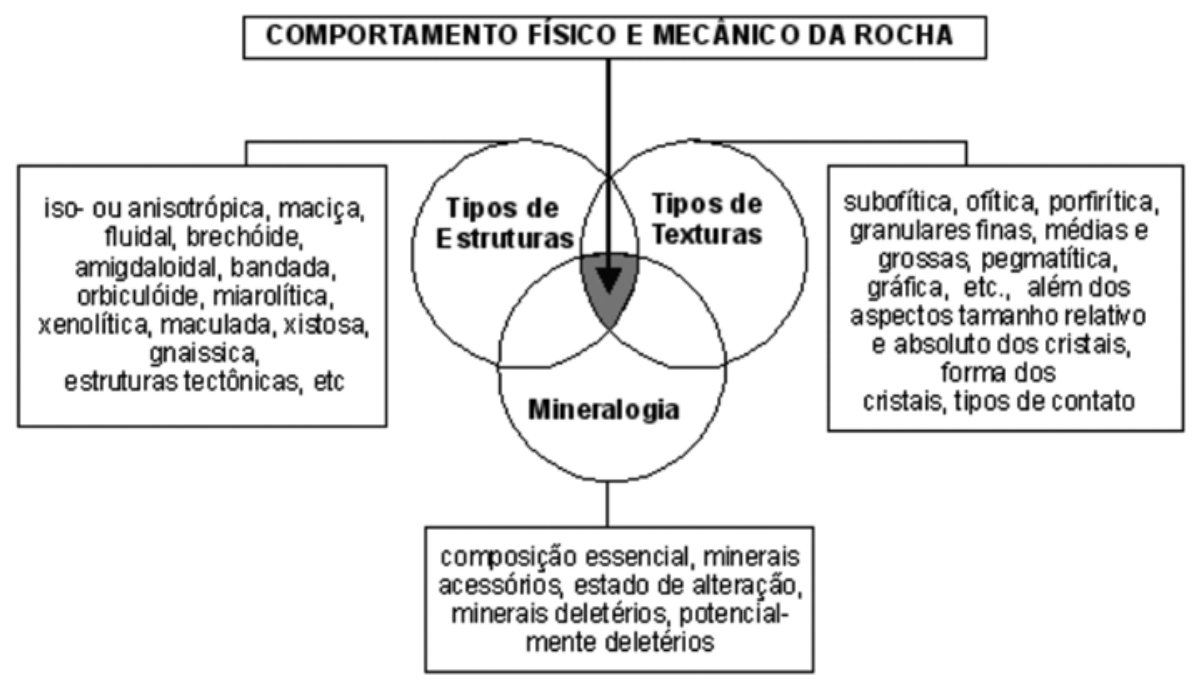

Figura 3 - Esquema ilustrando o comportamento fisico e mecânico de uma rocha, como resultado da interação entre os aspectos petrográficos definidos pela mineralogia, texturas e estruturas.

o de cor branca com tons amarelados ferruginosos, e "Juparaná Delicato", o de cor rosa com tons de preto. Considerando as diferenças apresentadas na textura e coloração destes gnaisses, acrescidas às feições encontradas em escala de afloramento, a análise petrográfica deu-se no sentido de conhecer mais detalhadamente as características intrínsecas de cada um deles, de forma que pudessem auxiliar na interpretação dos resultados obtidos nos ensaios físico-mecânicos assim como de envelhecimento acelerado com atmosfera salina.

Granada-biotita-muscovita gnaisse cinza esbranquiçado (Casablanca) - Trata-se de uma rocha grosseiramente gnaissificada, leucocrática, de cor branca com tons de cinza médio, nitidamente inequigranular de granulação média a média-grossa, com feições pegmatóides localizadas (Fig. 4). Em termos gerais é constituída por arcabouço quartzo-feldspático de granulação média contendo porções pegmatóides (leucossomas?) com formas lenticularizadas a alongadas de dimensões variadas, desde decimétricas a submétricas, e irregularmente espaçadas, entremeadas pela presença de microleitos descontínuos a lineares biotíticos-muscovíticos (melanossômicos?) com espessuras desde submilimétricas a cerca de 3 a $4 \mathrm{~mm}$. A granulação das porções pegmatóides é bastante variável, podendo localmente exibir cristais de feldspato potássico com dimensões que superam 2,0 a $3,0 \mathrm{~cm}$.

Por vezes ocorrem xenólitos de anfibolito inseridos na "matriz" quartzo-feldspática, fato este consoante com as complexas relações existentes entre as diferentes unidades da região, como por exemplo, o complexo máfico-ultramáfico acamadado de Tróia, rochas encaixantes de idade Arqueana.

A composição mineralógica modal média destes gnaisses, obtida pela integração através da quan-

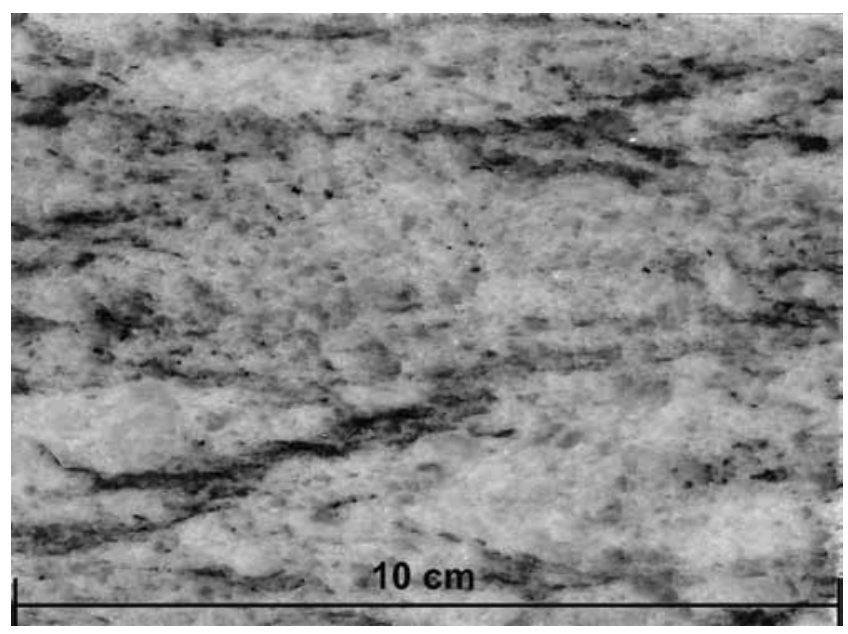

Figura 4 - Placa polida do gnaisse Casablanca, mostrando leitos descontínuos.

tificação macro e microscópica, é de cerca de 17,4\% de quartzo, $38 \%$ de plagioclásio (albita e oligoclásio), $28 \%$ de feldspato potássico (microclínio pertítico) e $13,2 \%$ de micas $(8,0 \%$ de muscovita e $5,2 \%$ de biotita) e 1,8\% de granada. Como minerais acessórios ocorrem os opacos, zircão e apatita, enquanto os secundários estão representados por sericita, epídoto, argilo-minerais, clorita e hidróxidos de ferro (Fig. 4a e Tab. 1).

Ao microscópio, este gnaisse apresenta textura granoblástica inequigranular orientada, com granulação bastante variável em função das porções quartzo-feldspáticas e dos leitos micáceos observados. As porções quartzo-feldspáticas do arcabouço do gnaisse (paleossoma gnaissificado?) exibem granulação média a média-fina $(0,5$ a $7,0 \mathrm{~mm}$ e, em média, entre 2,0 


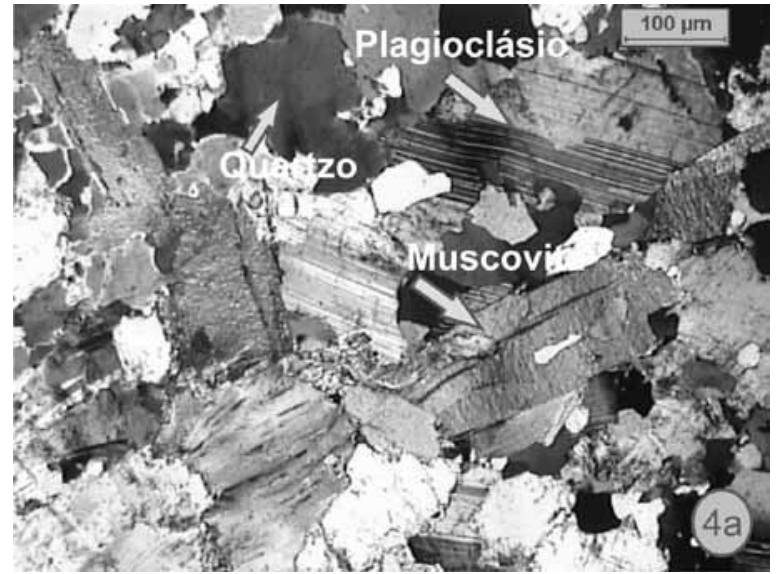

Figura $4 a$ - Fotomicrografia do Gnaisse Casablanca com nicóis cruzados. Muscovita e plagioclásio encurvados, apresentando extinção ondulante, característica de um primeiro estágio deformacional. Muscovita (Ms), Plagioclásio (Pl) e Quartzo (Qtz). e 4,0mm), sendo que nas porções pegmatóides as dimensões dos minerais excedem às das seções delgadas. Os leitos micáceos apresentam texturas lepidoblásticas a grano-lepidobláticas e granulação média-fina a média (em média entre 2,0 e $3,0 \mathrm{~mm}$ ).

O feldspato potássico está representado pelo microclínio e ocorre sob a forma de grãos subedrais e anedrais com reticulado em xadrez das maclas da albita e do periclínio. Nas porções pegmatóides é o mineral predominante e com as maiores dimensões, freqüentemente mesopertíticos e apresentando freqüentes inclusões de minúsculos cristais de quartzo, plagioclásio saussuritizado e alguma biotita.

O plagioclásio, caracterizado por uma composição na faixa albita-oligoclásio, é o mineral predominante na massa quartzo-feldspática de granulação média (paleossoma gnaissificado?) e bastante freqüente nos microleitos micáceos (melassômicos?). A albita constitui cerca de $15 \%$ da rocha e ocorre predominantemente sob a forma de anéis ou subanéis, manteando núcleos

Tabela 1 - Sintese dos dados petrográficos referentes ao Granada-biotita-muscovita gnaisse (Casablanca)

\begin{tabular}{|c|c|c|c|c|c|c|c|c|}
\hline \multirow{2}{*}{\multicolumn{3}{|c|}{$\begin{array}{l}\text { Nome Comercial } \\
\text { Amostra }\end{array}$}} & \multicolumn{6}{|c|}{ CASABLANCA } \\
\hline & & & CB1 & $\mathrm{CB} 2$ & CB3 & CB4 & CB5 & Valores Médios \\
\hline \multicolumn{3}{|c|}{ Mineralogia } & $\%$ & $\%$ & $\%$ & $\%$ & $\%$ & $\%$ \\
\hline \multicolumn{3}{|l|}{ Quartzo } & 15 & 16 & 19 & 19 & 18 & $17,4(17)$ \\
\hline \multicolumn{3}{|c|}{ Albita/Oligoclásio } & $15 / 31$ & $15 / 30$ & $14 / 30$ & $8 / 17$ & $10 / 20$ & $13 / 25$ \\
\hline \multicolumn{3}{|c|}{ Microclínio } & 20 & 22 & 20 & 40 & 38 & 28 \\
\hline \multicolumn{3}{|l|}{ Muscovita } & 9 & 7 & 9 & 8 & 7 & 8 \\
\hline \multicolumn{3}{|l|}{ Biotita } & 7 & 6 & 4 & 5 & 4 & 5,2 \\
\hline \multicolumn{3}{|l|}{ Granada } & 2 & 1,0 & 2 & 2 & 2 & $1,8(2)$ \\
\hline \multicolumn{3}{|c|}{ Acessórios (opacos) } & 0,5 & 2,5 & 1,3 & 0,5 & 0,6 & $1,1(1)$ \\
\hline \multicolumn{3}{|c|}{$\begin{array}{l}\text { Secundários (argilo-minerais, } \\
\text { sericita, clorita, epidoto e } \\
\text { hidróxido de ferro) }\end{array}$} & 0,5 & 0,5 & 0,7 & 0,5 & 0,4 & 0,5 \\
\hline \multicolumn{3}{|l|}{ Estrutura } & Gnáissica & Gnáissica & Gnáissica & Gnáissica & Gnáissica & Gnáissica \\
\hline \multicolumn{3}{|l|}{ Textura } & $\begin{array}{c}\text { Granoblástica/ } \\
\text { Granolepidoblástica }\end{array}$ & \begin{tabular}{|} 
Granoblástica/ \\
Granolepidoblástica
\end{tabular} & $\begin{array}{c}\text { Granoblástica/ } \\
\text { Granolepidoblástica }\end{array}$ & \begin{tabular}{|c|} 
Granoblástica/ \\
Granolepidoblástica
\end{tabular} & $\begin{array}{c}\text { Granoblástica/ } \\
\text { Granolepidoblástica }\end{array}$ & $\begin{array}{c}\text { Granoblástica/ } \\
\text { Granolepidoblástica }\end{array}$ \\
\hline \multirow{2}{*}{$\begin{array}{l}\text { Granulação } \\
(\mathrm{mm})\end{array}$} & \multicolumn{2}{|c|}{$\begin{array}{l}\text { Níveis } \\
\text { Granoblásticos }\end{array}$} & 4 a $10 \mathrm{~mm}$ & 9 a $10 \mathrm{~mm}$ & 6 a $8 \mathrm{~mm}$ & 8 a $10 \mathrm{~mm}$ & 6 a $8 \mathrm{~mm}$ & 6,6 a $9,2 \mathrm{~mm}$ \\
\hline & \multicolumn{2}{|c|}{\begin{tabular}{|l|} 
Níveis \\
Granolepidoblásticos
\end{tabular}} & $0,1 \mathrm{a} 1 \mathrm{~mm}$ & $0,5 \mathrm{a} 3 \mathrm{~mm}$ & $0,1 \mathrm{a} 2 \mathrm{~mm}$ & $0,3 \mathrm{a} 2 \mathrm{~mm}$ & $0,5 \mathrm{a} 3 \mathrm{~mm}$ & 0,3 a $2,2 \mathrm{~mm}$ \\
\hline \multicolumn{3}{|c|}{ Classificação (QAP) } & $\begin{array}{c}\text { Gnaisse } \\
\text { sienogranítico }\end{array}$ & $\begin{array}{c}\text { Gnaisse } \\
\text { sienogranítico }\end{array}$ & $\begin{array}{c}\text { Gnaisse } \\
\text { sienogranítico }\end{array}$ & $\begin{array}{c}\text { Gnaisse } \\
\text { sienogranítico }\end{array}$ & $\begin{array}{c}\text { Gnaisse } \\
\text { sienogranítico }\end{array}$ & $\begin{array}{c}\text { Gnaisse } \\
\text { sienogranítico }\end{array}$ \\
\hline \multirow{2}{*}{\multicolumn{2}{|c|}{$\begin{array}{l}\text { Microfissuras/ } \\
\mathrm{mm}^{2}\end{array}$}} & Intergrão & 0,03 & 0,06 & 0,12 & 0,04 & 0,04 & 0,06 \\
\hline & & Intragrão & 0,14 & 0,15 & 0,21 & 0,08 & 0,13 & 0,14 \\
\hline \multicolumn{3}{|l|}{ Alteração } & Fraca & Fraca & Fraca & Fraca & Fraca & Fraca \\
\hline \multirow{4}{*}{$\begin{array}{c}\text { Contatos } \\
(\%)\end{array}$} & \multicolumn{2}{|c|}{ Planos } & 2 & 7 & 7 & 6 & 6 & 5,6 \\
\hline & \multicolumn{2}{|c|}{ PI-serrilhados } & 23 & 23 & 25 & 18 & 12 & 20,2 \\
\hline & \multicolumn{2}{|c|}{ PI-lobulados } & 75 & 64 & 68 & 72 & 76 & 71 \\
\hline & \multicolumn{2}{|c|}{$\begin{array}{l}\text { Côncavo- } \\
\text { serrilhados }\end{array}$} & - & 6 & - & 4 & 6 & 3,2 \\
\hline
\end{tabular}


mais cálcicos (oligoclásio a andesina ácida, parcialmente saussuritizados) e, por vezes, intersticialmente aos demais minerais. $\mathrm{O}$ aspecto exibido pela albita sugere uma cristalização tardia para a mesma, provavelmente associada a uma fase metamórfica compatível com condições da fácies xisto verde médio-alto formada pela percolação de fluídos enriquecidos em sódio.

O quartzo ocorre comumente na forma de grãos anédricos com forte extinção ondulante, porém com forma poligonizada quando resultante de recuperação em subgrãos. Pode estar disposto intersticialmente ou como grãos isolados. Forma com o microclínio níveis quartzo-feldspáticos num arranjo granoblástico, por vezes poligonal.

Os cristais de granada ocorrem de forma subedral e anedral aparentemente ricas na molécula de almandina. Estão intensamente fraturados, ora exibindo cloritização ao longo das microfissuras, ora substituídos por filossilicatos castanhos.

Ocorrem duas fases micáceas. Uma primária representada por biotita e muscovita e uma secundária representada por muscovita e sericita. A existência de biotita passando a muscovita sugere retrometamorfismo na fase final de resfriamento dessa rocha. As relações de substituição entre as fases estão evidenciadas por restos de biotita presentes nos planos de clivagens de lamelas de muscovita.

A avaliação do percentual de alteração evidencia um processo de sericitização moderado nos feldspatos e nas micas. A alteração da rocha como um todo foi julgada fraca, apesar da aparência turva existente nos plagioclásios.

Quanto ao microfraturamento, é mais evidentes nos intragrãos do que nos intergrãos, sendo que nos primeiros o microfraturamento concentra-se principalmente nos cristais de quartzo e feldspatos enquanto que no segundo, a concentração se dá nas micas e em menor escala.

Os contatos do tipo plano-lobulados predominam com cerca de $71 \%$ das ocorrências, seguidos de aproximadamente $20 \%$ de contatos plano-serrilhados.

As observações macro e microscópica revelaram tratar-se de um gnaisse (migmatito nebulítico), originado a partir de intensa fusão parcial das rochas pretéritas (xistos ou gnaisses), e gnaissificado durante evento metamórfico superimposto, acompanhado por recalibração mineral sob condições metamórficas/metassomáticas mais brandas. Os efeitos tectonotermais superimpostos são bem evidenciados em lâmina delgada, pela observação de feições desenvolvidas nos cristais de quartzo, tais como banda de deformação e recuperação em subgrãos, formação de albita intersticial, além da isorientação geral das micas. Como subsídio para essa afirmação, temos ainda a associação mineral GRANADA + BIOTITA + QUARTZO + PLAGIOCLÁSIO + MICROCLÍNIO, característica de rochas formadas sob condições de $\mathrm{T}$ x P mais altas.

Granada-muscovita-biotita gnaisse rosado (Juparaná Delicato) - Refere-se a uma seqüência litológica com coloração rosada, grosseiramente gnaissificada, caracterizada por um arcabouço quartzo-feldspático gnáissico de granulação média (paleossoma?), contendo porções quartzo-feldspáticas de granulação média a grossa ou pegmatóide, com freqüentes texturas gráficas (neossoma granítico?) e com a presença de microleitos descontínuos a lineares biotíticos-muscovíticos (melanossomas?) (Fig. 5).

As porções quartzo-feldspáticas de granulação grossa a pegmatóide, com granulação que pode atingir dimensões centimétricas, constituem bolsões lenticulares a macroleitos isorientados com dimensões variadas, decimétricos a submétricos, com contornos irregulares e muitas vezes delineados por concentrações micáceas (melanossomas?).

As concentrações micáceas lineares apresentam espessuras reduzidas de, no máximo, alguns milímetros, mais ou menos persistentes e irregularmente distribuídas. Concentram-se preferencialmente nas bordas e no interior das porções quartzo-feldspáticas de granulação mais grossa a pegmatóides (leucossomáticas?), imprimindo, em termos gerais, um aspecto ligeiramente anastomosado à rocha.

A composição mineralógica modal média está representada essencialmente por $20,6 \%$ de quartzo, $36,4 \%$ de feldspato potássico (representado por microclínio), 26,6\% de plagioclásio (5,0\% de albita e 20,6\% de oligoclásio) e $13,8 \%$ de micas $(4,8 \%$ de muscovita e $9,0 \%$ de biotita) e cerca de $1,8 \%$ de granada, opacos, zircão e apatita, bem como $0,8 \%$ representados pelos minerais secundários sericita, epídoto, argilominerais e hidróxidos de ferro (Fig. 5a e Tab. 2).

Microscopicamente o gnaisse caracteriza-se por nítida textura essencialmente granoblástica, sendo que nas concentrações micáceas desenvolve texturas lepidoblástica a granolepidoblástica.

$\mathrm{O}$ feldspato potássico, representado pelo microclínio, ocorre normalmente sob a forma de grãos anedrais e subedrais, com típica geminação em grade e por vezes Carlsbad, exibindo fraturamento, com ou sem preenchi-

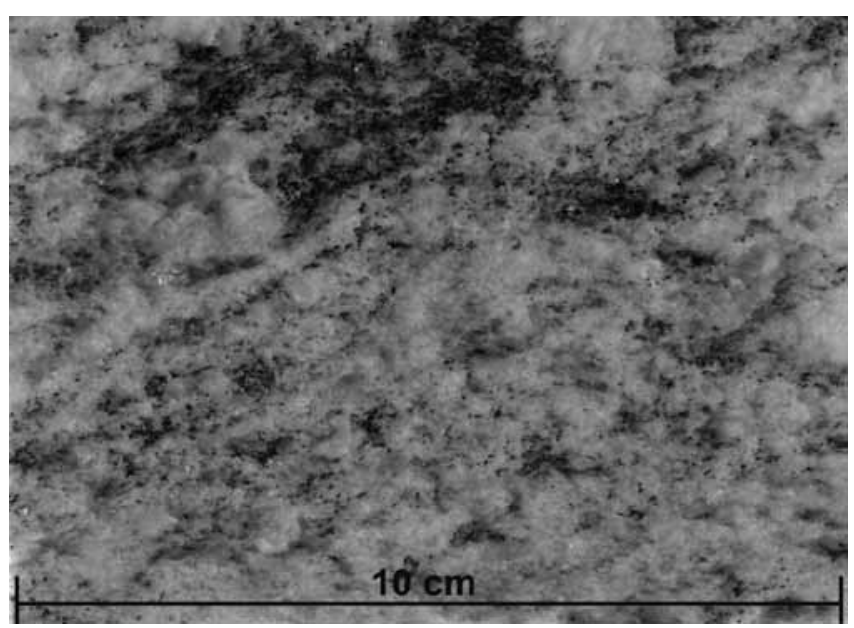

Figura 5 - Placa polida exibindo microleitos descontínuos a lineares biotíticos-muscoviticos, além de porções quartzo-feldspáticas de aspecto pegmatóide. 


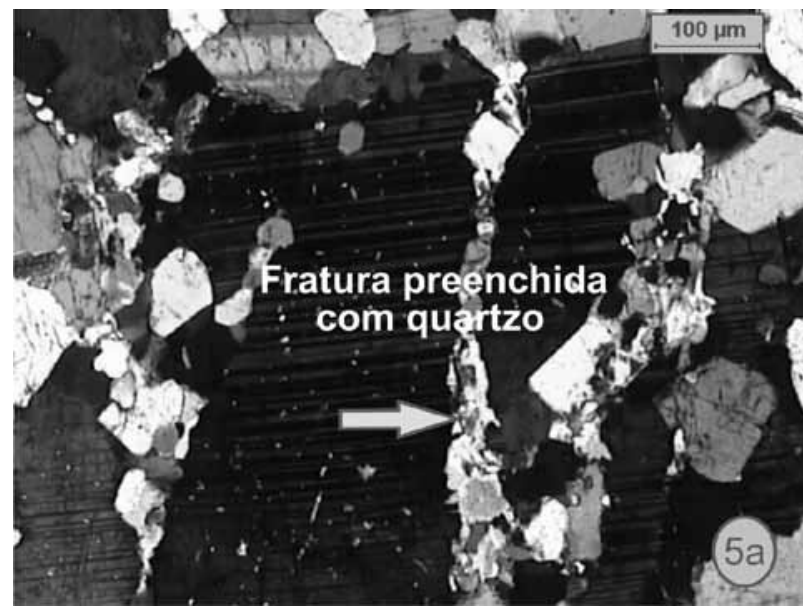

Figura 5a - Fotomicrografia do Gnaisse Delicato com nicóis cruzados. Albita com forma anédrica e dimensão maior, exibindo fratura preenchida com quartzo. Plagioclásio (Pl) e Quartzo (Qtz). mento por sericita, extinção ondulante e, mais raramente, contendo epídoto e opacos. Corresponde ao mineral amplamente predominante nas porções quartzo-feldspáticas pegmatóides, ocasiões em que apresentam certa riqueza em inclusões de minúsculos cristais de quartzo, plagioclásio saussuritizados e lamelas de biotita.

$\mathrm{O}$ plagioclásio está representado pela albita e por oligoclásio. A albita ocorre sob a forma de pequenos cristais anédricos (submilimétricos) intersticiais e, preferencialmente, formando delgados anéis manteando cristais maiores de oligoclásio. Este último pode ser zonado, com núcleos que atingem composição da andesina ácida, normalmente afetados por parcial sericitização, ou mesmo saussuritização, que lhes confere aspecto ligeiramente turvo.

A presença da albita sob a forma intersticial e de anéis emoldurando cristais de plagioclásio mais cálcicos sugere recalibrações minerais em condições metamórficas superimpostas mais brandas, ou efeitos retrometamórficos, acompanhados por percolação de fluidos enriquecidos em sódio.

Tabela 2 - Síntese dos dados petrográficos referentes ao Granada-muscovita-biotita gnaisse rosado (Juparaná Delicato)

\begin{tabular}{|c|c|c|c|c|c|c|c|}
\hline \multirow{2}{*}{\multicolumn{2}{|c|}{$\begin{array}{c}\text { Nome Comercial } \\
\text { Amostra } \\
\end{array}$}} & \multicolumn{6}{|c|}{ JUPARANÁ DELICATO } \\
\hline & & JD1 & $\mathrm{JD} 2$ & JD3 & JD4 & JD5 & Valores Médios \\
\hline \multicolumn{2}{|c|}{ Mineralogia } & $\%$ & $\%$ & $\%$ & $\%$ & $\%$ & $\%$ \\
\hline \multicolumn{2}{|c|}{ Quartzo } & 23 & 17 & 14 & 28 & 21 & $20,6(20)$ \\
\hline \multicolumn{2}{|c|}{ Albita/Oligoclásio } & $4 / 16$ & $3 / 15$ & $4 / 15$ & $9 / 40$ & $5 / 17$ & $5,0 / 20,6(26)$ \\
\hline \multicolumn{2}{|c|}{ Microclínio } & 39 & 43 & 53 & 9 & 38 & 36,4 \\
\hline \multicolumn{2}{|c|}{ Biotita } & 9 & 12 & 7 & 6 & 11 & 9 \\
\hline \multicolumn{2}{|c|}{ Muscovita } & 6 & 6 & 3 & 4 & 5 & $4,8(5)$ \\
\hline \multicolumn{2}{|c|}{$\begin{array}{l}\text { Acessórios (granada, opacos, } \\
\text { zircão, apatita) }\end{array}$} & 1 & 2,5 & 2 & 2 & 1,5 & 1,8 \\
\hline \multicolumn{2}{|c|}{$\begin{array}{c}\text { Secundários (argilo-minerais, } \\
\text { sericita, biotita, epidoto e óxido } \\
\text { de ferro) }\end{array}$} & 0 & 0,5 & 1 & 1 & 0,5 & 0,8 \\
\hline \multicolumn{2}{|c|}{ Estrutura } & Gnáissica & Gnáissica & Gnáissica & Gnáissica & Gnáissica & Gnáissica \\
\hline \multicolumn{2}{|c|}{ Textura } & $\begin{array}{c}\text { Granoblástica/ } \\
\text { Granolepidoblástica }\end{array}$ & $\begin{array}{c}\text { Granoblástica/ } \\
\text { Granolepidoblástica }\end{array}$ & \begin{tabular}{|} 
Granoblástica/ \\
Granolepidoblástica
\end{tabular} & $\begin{array}{c}\text { Granoblástica/ } \\
\text { Granolepidoblástica }\end{array}$ & $\begin{array}{l}\text { Granoblástica/ } \\
\text { Granolepidoblástica }\end{array}$ & $\begin{array}{l}\text { Granoblástica/ } \\
\text { Granolepidoblástica }\end{array}$ \\
\hline \multirow{2}{*}{$\begin{array}{l}\text { Granulação } \\
(\mathrm{mm})\end{array}$} & $\begin{array}{c}\text { Níveis } \\
\text { granoblásticos }\end{array}$ & 8 a $14 \mathrm{~mm}$ & 7 a $13 \mathrm{~mm}$ & 7 a $14 \mathrm{~mm}$ & 5 a $12 \mathrm{~mm}$ & 7 a $13 \mathrm{~mm}$ & 6,8 a $13 \mathrm{~mm}$ \\
\hline & \begin{tabular}{c|} 
Níveis \\
granolepidoblásticos
\end{tabular} & $0,1 \mathrm{a} 2,0 \mathrm{~mm}$ & 0,5 a $2 \mathrm{~mm}$ & 0,3 a $1,5 \mathrm{~mm}$ & 0,5 a $2,0 \mathrm{~mm}$ & $1 \mathrm{a} 2 \mathrm{~mm}$ & 0,5 a $1,9 \mathrm{~mm}$ \\
\hline \multicolumn{2}{|c|}{ Classificação (QAP) } & $\begin{array}{c}\text { Gnaisse } \\
\text { sienogranítico }\end{array}$ & $\begin{array}{c}\text { Gnaisse } \\
\text { sienogranítico } \\
\end{array}$ & $\begin{array}{c}\text { Gnaisse } \\
\text { sienogranítico } \\
\end{array}$ & $\begin{array}{c}\text { Gnaisse } \\
\text { sienogranítico } \\
\end{array}$ & $\begin{array}{c}\text { Gnaisse } \\
\text { sienogranítico } \\
\end{array}$ & $\begin{array}{c}\text { Gnaisse } \\
\text { sienogranítico } \\
\end{array}$ \\
\hline \multirow{2}{*}{$\begin{array}{l}\text { Microfissuras } \\
/ \mathrm{mm}^{2}\end{array}$} & Intergrão & 0,03 & 0,05 & 0,10 & 0,03 & 0,04 & 0,04 \\
\hline & Intragrão & 0,13 & 0,14 & 0,19 & 0,07 & 0,12 & 0,13 \\
\hline \multicolumn{2}{|c|}{ Alteração } & Fraca & Fraca & Fraca & Fraca & Fraca & Fraca \\
\hline \multirow{4}{*}{ Contatos (\%) } & Planos & 9 & 10 & 16 & 13 & 8 & $11,2(11)$ \\
\hline & PI-serrilhados & 20 & 30 & 25 & 22 & 25 & $24,4(24)$ \\
\hline & PI-lobulados & 71 & 60 & 55 & 65 & 60 & $62,2(62)$ \\
\hline & $\begin{array}{l}\text { Côncavo- } \\
\text { serrilhados }\end{array}$ & - & - & 4 & - & 7 & 3 \\
\hline
\end{tabular}


Os grãos de quartzo em geral formam mosaico granoblástico com formas anedrais a subedrais, exibindo extinção ondulante. Bandas de deformação também são observadas com efeitos de recristalização.

As micas apresentam-se comumente em agregados lamelares deformados e em lamelas individuais. Freqüentemente exibem os planos de clivagem preenchidos por minúsculos cristais de opacos sob forma disseminada. A evidência de retrometamorfismo também é constatada por processos de muscovitização parcial de cristais de biotita, bem como pela coexistência de albita-oligoclásio, caracterizando provável transição de condições da fácies xisto verde a anfibolito.

A biotita concentra-se preferencialmente nos leitos melanossômicos que normalmente delineiam porções quartzo-feldspáticas de granulação mais grossa a pegmatóide, aonde juntamente com a muscovita conduzem a aspectos texturais tipicamente lepidoblásticos a granolepidoblásticos, responsáveis pelo desenvolvimento de evidentes planos de descontinuidades físicas na rocha.

A granada é o mineral acessório mais significativo, apresenta grãos anedrais fraturados com presença de biotita e clorita em suas bordas e interstícios.

Ocorre o predomínio de microfissuras intragrãos, com cerca de 0,13 microfissuras $/ \mathrm{mm}^{2}$, fechadas ou preenchidas por sericita, argilominerais incolores e mais raramente contendo algum epidoto. As fissuras intergrãos são preenchidas por quartzo recristalizado ou grãos de biotita isorientados, formando níveis lineares descontínuos de espessuras submilimétricas.

Há a predominância de contatos plano-lobulados com cerca de $62 \%$ das ocorrências e $24 \%$ de contatos plano-serrilhados.

Granada-muscovita-biotita gnaisse branco amarelado (Giallo Falésia) - Trata-se da facies intempericamente alterada dos leucognaisses objeto desta pesquisa, destacando-se pela marcante alteração cromática e pela presença de clorita em microfraturas de granada, além de microfissuras mais largas e preenchidas. As superfícies dos grãos, principalmente ao longo dos planos micáceos, encontramse permeadas por material amarelo-ferruginoso.

Rocha gnáissica leucocrática de coloração branco amarelada inequigranular, de granulação variando de média a grossa, com porções tipicamente pegmatóides (Fig. 6). Corresponde a um material petrograficamente bastante heterogêneo, tanto sob aspectos texturais/estruturais quanto composicionais, definido pela alternância de bandas lenticulares irregulares ora quartzo-feldspáticas (graníticas), de granulação grossa a pegmatóide, ora gnáissicas, de granulação média com maior ou menor riqueza de microleitos micáceos (melanossômicos), em geral grosseiramente isorientadas. As bandas lenticulares apresentam dimensões e espessuras variadas, centimétricas a métricas, irregularmente distribuídas e com contatos gradacionais e difusos entre si.

Os microleitos micáceos, com predominância de biotita sobre a muscovita, são descontínuos a persistentes com espessuras submilimétricas a milimétricas, isorientados, podendo ocorrer tanto isoladamente quanto

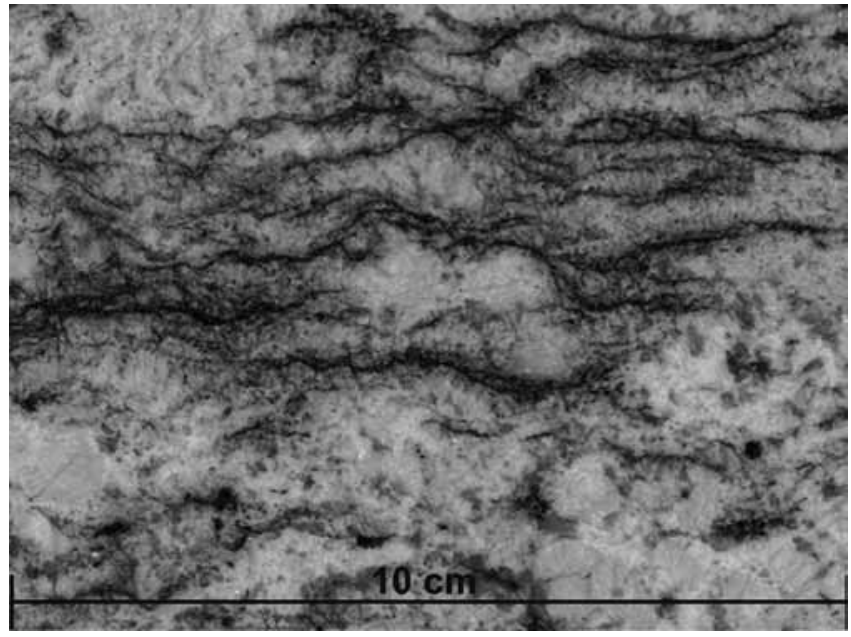

Figura 6 - Placa polida do Gnaisse Falésia exibindo concentrações lineares de minerais micáceos com espessuras milimétricas.

concentrados em certas porções da rocha, ocasiões em que imprimem aspecto mais ou menos bandado ao material. Em termos gerais os microleitos micáceos representam prováveis concentrações melanossômicas e, como tais, são responsáveis pelo desenvolvimento de planos de descontinuidades físicas com conseqüente redução da resistência mecânica das rochas. Destaca-se que os cristais de biotita destes microleitos encontram-se relativamente oxidados com a formação e conseqüente liberação de hidróxidos de ferro, os quais pela dispersão através das microfissuras e interfácies minerais, conferem à rocha manchas aleatórias de coloração amarelada com faixas irregulares de aspectos ferruginosos.

A composição mineralógica modal média deste gnaisse está representada por cerca de $18,8 \%$ de quartzo, $36,4 \%$ de feldspato potássico, $26,6 \%$ de plagioclásio (aproximadamente $6,0 \%$ de albita e $35,0 \%$ de oligoclásio), $10,0 \%$ de biotita, $5,0 \%$ de muscovita, além de $2,2 \%$ de granada, opacos, zircão e apatita. Como minerais secundários ocorrem sericita, epidoto, argliominerais, óxidos e hidróxidos de ferro. Microscopicamente apresenta textura predominantemente granoblástica com presença de típicas feições lepidoblásticas nos microleitos micáceos (Fig. 6a e Tab. 3).

O feldspato potássico corresponde ao microclínio, podendo ser fortemente pertítico, com cristais anédricos e subédricos caracterizados por nítida geminação em grade, freqüentemente exibindo microfissuramentos, recristalização e por vezes extinção ondulante. Representa o mineral mais freqüente das porções quartzo-feldspáticas de granulação grossa a pegmatóide, ocasiões em que atinge as maiores dimensões. Por vezes encontra-se parcialmente sericitizado e com variável intensidade de argilização, o que lhe imprime aspecto turvo devido à presença de pigmentação dada por hidróxidos de ferro.

O plagioclásio apresenta composição na faixa albita-oligoclásio e representa o feldspato mais fre- 


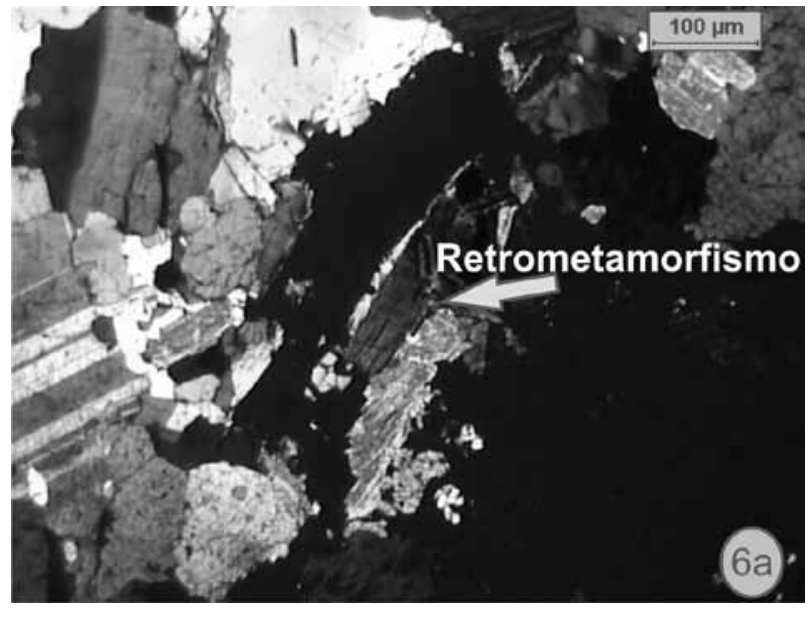

Figura 6 a - Fotomicrografia do Gnaisse Falésia com nicóis cruzados. Muscovitização da biotita, evidência de retrometamorfismo. Plagioclásio (Pl), Biotita (Bt) e Ms (Muscovita). qüente das porções gnáissicas de granulação média a média-fina (restos paleossômicos?) e nas faixas e concentrações enriquecidas em micas. A albita ocorre tanto sob a forma de pequenos cristais anédricos intersticialmente aos demais minerais quanto formando delgados anéis descontínuos que emolduram parcialmente cristais de plagioclásio mais cálcico (oligoclásio com núcleos que podem atingir a composição de andesina ácida). Os cristais mais cálcicos exibem, com freqüência, núcleos parcial a totalmente sericitizados e por vezes encontram-se intensamente saussuritizados.

Os microfissuramentos minerais, bem como os interstícios dos grãos, em sua maioria encontram-se preenchidos por um material ferruginoso, proveniente de minerais opacos e da biotita. Os grãos menores de plagioclásio que se encontram formando os níveis quartzo-feldspáticos exibem boa geminação e forma subedral. No entanto, os grãos maiores têm forma anedral e mostram-se bastante fraturados, fraturas estas

Tabela 3 - Síntese dos dados petrográficos referentes ao Granada-muscovita-biotita gnaisse branco amarelado (Giallo Falésia).

\begin{tabular}{|c|c|c|c|c|c|c|c|}
\hline \multicolumn{2}{|c|}{ Nome Comercial } & \multicolumn{6}{|c|}{ GIALLO FALÉSIA } \\
\hline \multicolumn{2}{|l|}{ Amostra } & FL1 & FL2 & FL3 & FL4 & FL5 & Valores Médios \\
\hline \multicolumn{2}{|l|}{ Mineralogia } & $\%$ & $\%$ & $\%$ & $\%$ & $\%$ & $\%$ \\
\hline \multicolumn{2}{|l|}{ Quartzo } & 17 & 19 & 12 & 26 & 20 & $18,8(19)$ \\
\hline \multicolumn{2}{|c|}{ Albita/Oligoclásio } & 45 & 41 & 46 & 36 & 37 & $6 / 35$ \\
\hline \multicolumn{2}{|l|}{ Microclínio } & 20 & 23 & 24 & 25 & 25 & $23,4(23)$ \\
\hline \multicolumn{2}{|l|}{ Biotita } & 7 & 7 & 8 & 6 & 10 & $7,6(8)$ \\
\hline \multicolumn{2}{|l|}{ Muscovita } & 7 & 6 & 7 & 5 & 5 & 6 \\
\hline \multicolumn{2}{|c|}{ Acessórios (opacos e granada) } & 3 & 3 & 2 & 1 & 2 & $2,2(2)$ \\
\hline \multicolumn{2}{|c|}{$\begin{array}{l}\text { Secundários (argilo-minerais, sericita, } \\
\text { óxido de ferro, epidoto e clorita) }\end{array}$} & 1 & 1 & 1 & 1 & 1 & 1 \\
\hline \multicolumn{2}{|l|}{ Estrutura } & Gnáissica & Gnáissica & Gnáissica & Gnáissica & Gnáissica & Gnáissica \\
\hline \multicolumn{2}{|l|}{ Textura } & $\begin{array}{l}\text { Granoblástica/ } \\
\text { granolepido } \\
\text { blástica }\end{array}$ & $\begin{array}{l}\text { Granoblástica/ } \\
\text { granolepido } \\
\text { blástica }\end{array}$ & $\begin{array}{l}\text { Granoblástica/ } \\
\text { granolepido } \\
\text { blástica }\end{array}$ & $\begin{array}{l}\text { Granoblástica/ } \\
\text { granolepido } \\
\text { blástica }\end{array}$ & $\begin{array}{l}\text { Granoblástica/ } \\
\text { granolepido } \\
\text { blástica }\end{array}$ & $\begin{array}{l}\text { Granoblástica/ } \\
\text { granolepido } \\
\text { blástica }\end{array}$ \\
\hline \multirow{2}{*}{$\begin{array}{r}\text { Granulação } \\
(\mathrm{mm})\end{array}$} & $\begin{array}{l}\text { Níveis } \\
\text { granoblásticos }\end{array}$ & 7 a $15 \mathrm{~mm}$ & 5 a $13 \mathrm{~mm}$ & 5 a $12 \mathrm{~mm}$ & 4 a $10 \mathrm{~mm}$ & 4 a $12 \mathrm{~mm}$ & 5 a $12,4 \mathrm{~mm}$ \\
\hline & Niveis granolepidoblásticos & $1 \mathrm{a} 2,5 \mathrm{~mm}$ & 1,5 a $2,5 \mathrm{~mm}$ & $1 \mathrm{a} 2,0 \mathrm{~mm}$ & $1 \mathrm{a} 2,5 \mathrm{~mm}$ & 1,5 a $2,0 \mathrm{~mm}$ & 1,2 a $2,3 \mathrm{~mm}$ \\
\hline \multicolumn{2}{|c|}{ Classificação (QAP) } & $\begin{array}{c}\text { Gnaisse } \\
\text { Sienogranítico }\end{array}$ & $\begin{array}{c}\text { Gnaisse } \\
\text { Sienogranítico }\end{array}$ & $\begin{array}{c}\text { Gnaisse } \\
\text { Sienogranítico }\end{array}$ & $\begin{array}{c}\text { Gnaisse } \\
\text { Sienogranítico }\end{array}$ & $\begin{array}{c}\text { Gnaisse } \\
\text { Sienogranítico }\end{array}$ & $\begin{array}{c}\text { Gnaisse } \\
\text { Sienogranítico }\end{array}$ \\
\hline \multirow{2}{*}{$\begin{array}{r}\text { Microfissuras } \\
/ \mathrm{mm}^{2}\end{array}$} & Intergrão & 0,05 & 0,07 & 0,14 & 0,06 & 0,07 & 0,08 \\
\hline & Intragrão & 0,16 & 0,17 & 0,23 & 0,09 & 0,15 & 0,18 \\
\hline \multicolumn{2}{|l|}{ Alteração } & Moderada & Moderada & Moderada & Moderada & Moderada & Moderada \\
\hline \multirow{4}{*}{ Contatos (\%) } & Planos & 9 & 10 & 16 & 13 & 8 & $11,2(11)$ \\
\hline & PI-serrilhados & 20 & 30 & 25 & 22 & 25 & $24,4(24)$ \\
\hline & PI-lobulados & 71 & 60 & 55 & 65 & 60 & $62,2(62)$ \\
\hline & Côncavo-serrilhados & - & - & 4 & - & 7 & 3 \\
\hline
\end{tabular}


preenchidas por grãos hexagonais de quartzo que caracterizam uma dinâmica estática.

Os grãos de quartzo podem ocorrer de forma individualizada ou constituírem mosaicos granoblásticos, por vezes microfissurados (algumas microfissuras encontram-se preenchidas por materiais de alteração). Os efeitos de extinção ondulante e recristalização são bem mais intensos do que nos feldspatos.

Nos agregados micáceos verifica-se a predominância da biotita sobre a muscovita. De forma similar aos outros minerais essenciais, a biotita exibe extinção ondulante e recristalização com recuperação em sublamelas. A muscovita ocorre, quase sempre, na forma de agregados ou lamelas reliquiares com microfissuras preenchidas por hidróxido de ferro liberado a partir da oxidação da biotita.

Os minerais acessórios mais significativos compõem-se de granada e minerais opacos, enquanto os secundários estão representados por minerais de argila neoformados, sericita, epídoto, óxido e hidróxidos de ferro e alguma clorita.

Os contatos entre grãos são dominantemente plano-lobulados (62\% das ocorrências) e plano-serrilhados (24\%).

Também neste litotipo predominam microfissuras intragrãos, com cerca de 0,18 microfissuras $/ \mathrm{mm}^{2}$. Contudo, o número de fissuras intergrão é bem mais significativo do que nos outros dois litotipos estudados, além do que as fissuras mostram-se mais espessas e maiores.

Os processos de alteração considerados moderados concentram-se em plagioclásios e subordinadamente em micas (processos de muscovitização de biotita). Entretanto, a rocha exibe uma forte dispersão de material ferruginoso nas microfissuras e interstícios de grãos. Este processo parece estar relacionado à presença de opacos (óxidos de ferro) e ao posicionamento estrutural da jazida.

Similarmente aos outros dois gnaisses anteriormente descritos, as feições texturais, estruturais e composicionais exibidas pelo gnaisse sugerem que o mesmo corresponde a um migmatito nebulítico a homofânico originado pela fusão parcial das rochas pretéritas (xistos ou gnaisses), e gnaissificado durante evento metamórfico superimposto acompanhado por recalibração mineral sob condições metamórficas/metassomáticas mais brandas ou retrometamórficas.

ASPECTOS FÍSICOS E TECNOLÓGICOS E RELAÇÃO COM A CONDUTIVIDADE TÉRMICA O gnaisse Falésia apresentou, comparativamente, menores valores de massa específica e maiores valores de porosidade e absorção d'água, confirmando a existência de um volume maior de vazios (poros, fissuras etc.) desta variedade em relação às demais (Tab. 4). Trata-se de parâmetros bastante significativos por influenciarem diretamente nas demais propriedades físicas, na reatividade química e, conseqüentemente, na resistência e durabilidade do material.

De acordo com os resultados do ensaio de resistência ao natural e à classificação da ISRM (1979), os gnaisses Delicato (115,2MPa) e Casablanca (100,4MPa) podem ser considerados muito resistentes, enquanto o Falésia $(75,25 \mathrm{MPa})$ situa-se na categoria de rocha resistente (Fig. 7). As resistências relativamente elevadas destas rochas ao natural devem-se ao bom imbricamento mineral que elas apresentam com recristalização em grãos e subgrãos de quartzo o que confere à textura níveis/faixas com característica de mosaico granoblástico.

$\mathrm{O}$ ensaio de velocidade de propagação de ondas ultra-sônicas longitudinais, por ser não destrutivo, além de funcionar como parâmetro de seleção para as amostras, também pode ser utilizado como instrumento auxiliar nas interpretações de resultados. Na avaliação realizada com as amostras ao natural, o Delicato apresentou valores mais altos $(6514 \mathrm{~m} / \mathrm{s})$, denotando uma maior coesão desta rocha em relação às demais estudadas (Fig. 8). O Falésia apresentou, em média, os menores valores obtidos para esta propriedade, reflexo da maior alteração mineral e do maior grau de microfissuramento neste litotipo $(2759 \mathrm{~m} / \mathrm{s})$. O Casablanca situou-se numa posição intermediária entre os demais $(3453 \mathrm{~m} / \mathrm{s})$. Contudo, vale ressaltar que variações de dados encontradas ao longo de toda esta pesquisa refletem a estruturação muito heterogênea dessas rochas, o que praticamente impossibilitou

Tabela 4 - Valores médios de indices físicos dos gnaisses Casablanca, Delicato e Falésia ao natural.

\begin{tabular}{c|c|c|c|c}
\hline \multicolumn{5}{c|}{ ÍNDICES FÍSICOS - NATURAL } \\
\hline AMOSTRA & $\begin{array}{c}\text { MASSA ESP. } \\
\text { APARENTE } \\
\text { SECA }\end{array}$ & $\begin{array}{c}\text { MASSA ESP. } \\
\text { APARENTE } \\
\text { SATURADA }\end{array}$ & $\begin{array}{c}\text { POROSIDADE } \\
\text { APARENTE } \\
(\%)\end{array}$ & $\begin{array}{c}\text { ABSORÇÃO } \\
\text { DE } \\
\text { ÁGUA (\%) }\end{array}$ \\
\hline $\begin{array}{c}\text { Casablanca } \\
\text { Juparaná }\end{array}$ & 2.648 & 2.654 & 0,42 & 0,16 \\
\hline $\begin{array}{c}\text { Giallo } \\
\text { Falésia }\end{array}$ & 2.627 & 2.650 & 0,46 & 0,18 \\
\hline
\end{tabular}

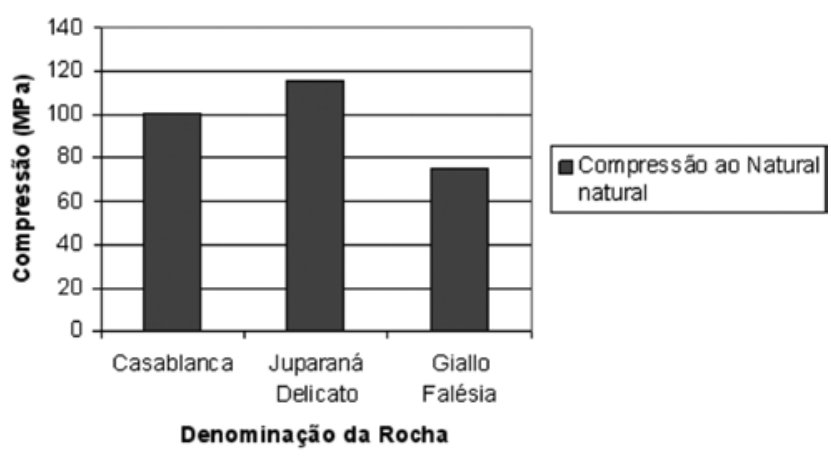

Figura 7 - Resistência à compressão dos gnaisses Casablanca, Delicato e Falésia. 


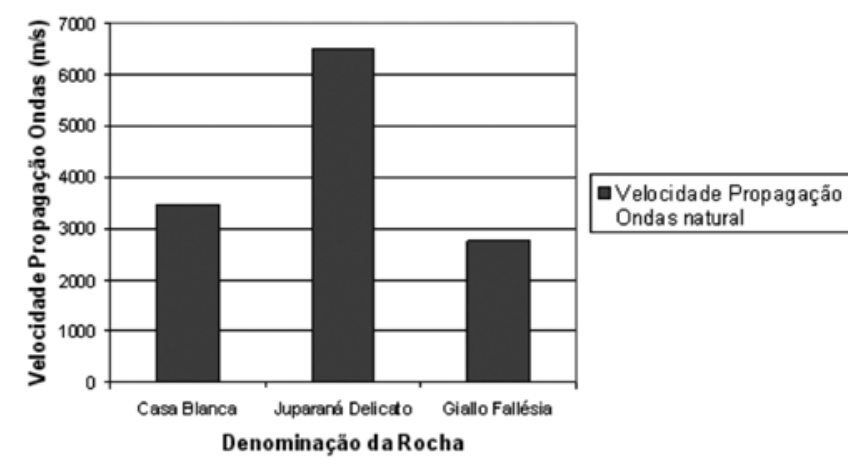

Figura 8 - Propagação de ondas ao natural nos gnaisses Casablanca, Delicato e Falésia.

a obtenção de corpos-de-prova representativos das suas diferenças estruturais e mineralógicas.

Os valores de dilatação térmica determinados com as amostras no seu estado natural situam-se entre 5 e $7 \times 10^{-3} \mathrm{~mm} /\left(\mathrm{m}^{\circ} \mathrm{C}\right)$ e, portanto, próximos daqueles encontrados por Lima (2002) para rochas gnáissicas. O Falésia apresentou os maiores valores de dilatação térmica dentre os três litotipos em virtude do maior quantitativo de biotita, considerando a susceptibilidade deste mineral à fadiga térmica que incorre no alargamento de linhas de clivagem. Os resultados mostraram que o Falésia e o Delicato foram os que sofreram variação mais significativa de seus coeficientes em função do ensaio acelerado (Fig. 9), porém se mantiveram abaixo do limite sugerido por Frazão e Farjallat (1995) que é $\beta \leq 12 \times 10^{-3} \mathrm{~mm} /$ $\left(\mathrm{m}^{\circ} \mathrm{C}\right)$. A forte anisotropia das rochas gnáissicas resulta em diferentes valores de dilatação térmica sendo o valor de $\beta$ sempre maior quando determinado paralelo à gnaissificação (Lima 2002). Com exceção do Casablanca, os demais seguiram esta tendência, podendo o comportamento anômalo daquela rocha ser explicado pela irregularidade dos bandeamentos presentes que ora exibem níveis com espessuras reduzidas e/ou descontinuidades.

Os resultados do ensaio de aptidão de molhagem também salientam a heterogeneidade dessas rochas, coincidindo os valores mais baixos com zonas mais ricas em minerais micáceos e de maior incidência de microfissuras. Essas zonas funcionam como pontos ou áreas de maior fragilidade, servindo de porta de entrada para os contaminantes. No ensaio realizado com estes exemplares, verificou-se que o Falésia, em média, apresentou os menores valores, por conter um percentual maior de minerais micáceos e microfissuras, seguido do Delicato e Casablanca (Fig. 10). Este resultado expressa uma maior aptidão de molhagem do Falésia em relação aos demais, fato que se coaduna com os resultados obtidos nos ensaios de absorção e porosidade. A mineralogia, textura e os aspectos físicos determinaram o comportamento da condutividade térmica nas rochas. Os três litotipos aqui estudados, Casablanca, Juparaná Delicato e Giallo Falésia, são petrograficamente muito similares: granada-biotita-muscovita gnaisse, granada- muscovita-biotita gnaisse e granadamuscovita-biotita gnaisse, respectivamente. Contudo, apresentam certas mudanças texturais que, a principio, não influenciam significativamente nos resultados de condutividade térmica (Figueiredo et al. 2008). Dessa

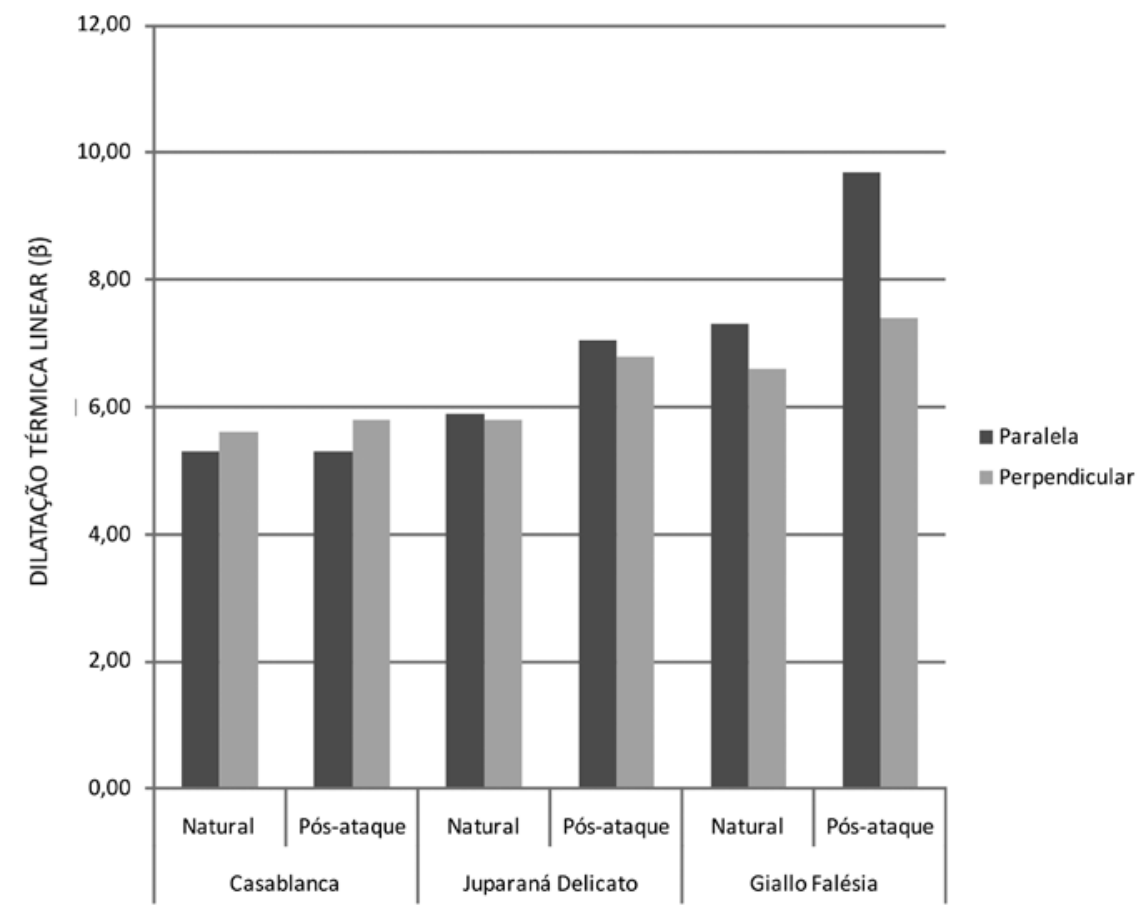

Figura 9 - Dilatação Térmica Linear antes e depois do ensaio de alteração acelerada (1080h). 


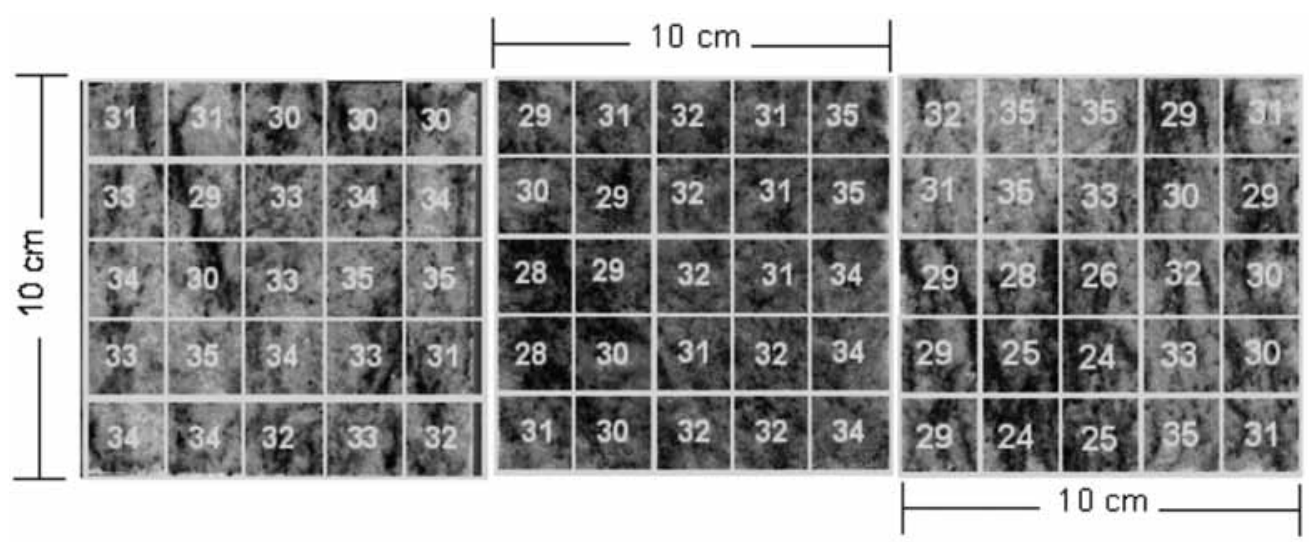

Figura 10 - Valores de tp nas diferentes áreas de placas dos gnaisses Casablanca, Delicato e Falésia.

forma, é possível minimizar o efeito destes parâmetros, uma vez que em teoria os três litotipos deveriam apresentar condutividades térmicas similares. As três amostras se comportam como rochas de média a alta condutividade térmica, cujos valores variam de $2,79 \mathrm{~W} / \mathrm{m}^{\circ} \mathrm{K}$, para medida 4 do Falésia, até $4,41 \mathrm{~W} / \mathrm{m}^{\circ} \mathrm{K}$ para medida 1 do Delicato. O Delicato mostrou os maiores valores de condutividade térmica com média igual a $3,64 \mathrm{~W} / \mathrm{m}^{\circ} \mathrm{K}$. As medidas 1,2 e 4 desta rocha, mostraram-se fortemente influenciadas pela presença de quartzo em quantidade bastante significativas gerando valores muito altos. Já para a medida de número 3 , nota-se uma considerável diminuição provocada, possivelmente, pelo aumento de feldspato e conseqüente diminuição de quartzo. O Casablanca mostrou valores de condutividade térmica considerados altos, contudo com média pouco inferior ao Delicato. A média do Casablanca situou-se em torno de $3,19 \mathrm{~W} / \mathrm{m}^{\circ} \mathrm{K}$. Os valores obtidos nas quatro regiões ficaram dentro da margem de erro do equipamento, inviabilizando, portanto, qualquer comparação entre as medidas (Tab. 5). Por fim, o Falésia mostrou os menores valores, com média de $2,99 \mathrm{~W} / \mathrm{m}^{\circ} \mathrm{K}$. Especificamente a região de número 4 apresentou valor consideravelmente reduzido, sendo este decréscimo creditado à ocorrência de microfissuras naquela região.

Tabela 5 - Valores de condutividade térmica $(\kappa)$ dos gnaisses estudados.

\begin{tabular}{c|c|c|c}
\hline & \multicolumn{3}{|c}{ CONDUTIVIDADE TÉRMICA $(\kappa)$} \\
\hline \multirow{2}{*}{$\begin{array}{c}\text { PONTOS DE } \\
\text { MEDIÇÃO }\end{array}$} & CASABLANCA & DELICATO & FALÉSIA \\
\cline { 2 - 4 } & 3,28 & 4,41 & 3,16 \\
A - 1 & 3,17 & 3,55 & 2,98 \\
A - 2 & 3,09 & 3,11 & 3,03 \\
A - 3 & 3,22 & 3,48 & 2,79 \\
A - 4 & 3,19 & 3,64 & 2,99 \\
Média & \multicolumn{3}{|c}{} \\
\hline
\end{tabular}

Acredita-se que estes valores de condutividade térmica podem sofrer significativo aumento se a rocha for exposta a aerossóis marinhos, uma vez que estes aerossóis percolam poros e fissuras, carreando e depositando sais como a halita $(\mathrm{NaCl})$ que apresenta coeficiente de condutividade térmica consideravelmente maior $\left(\kappa_{\mathrm{NaCl}}=26,7\right)$.

CONCLUSÕES De maneira geral os resultados de condutividade térmica, apesar de sofrerem influências locais de mineralogia, refletem as características físicas gerais de cada litotipo. Litotipos com mineralogias similares e com diferenças nas texturas, aparentemente não muito expressivas, deveriam apresentar respostas similares aos ensaios. Neste caso específico, as características físicas discrepantes influenciam de forma significativa, os resultados inclusive os de condutividade térmica.

Verifica-se que os valores mais baixos de condutividade térmica $(\kappa)$ obtidos no gnaisse Falésia são compatíveis com os resultados de seus índices físicos, uma vez que a condutividade será tanto menor quanto maior for a porosidade da rocha, ou quanto mais baixa for a massa específica aparente da mesma (Frazão 2002).

O Delicato apresentou valores mais altos no ensaio de velocidade de propagação de ondas ultrasônicas longitudinais realizado ao natural, denotando uma maior coesão desta rocha em relação às demais estudadas. O Falésia apresentou, em média, os menores valores obtidos para esta propriedade, reflexo de maior grau de microfissuramento e de minerais alterados neste litotipo. O Casablanca situou-se numa posição intermediária entre os demais, com valores próximos daqueles obtidos por Frascá (2003) para o mesmo gnaisse.

Os menores valores de velocidade de ultra-sons encontrados para o Casablanca e Falésia podem ser, inicialmente, atribuídos à maior concentração de biotita nessas amostras, feição esta presentes nas porções gnáissicas das mesmas. Os menores valores, dentre todos, foram determinados no Falésia e são controlados pelos níveis micáceos e pelo grau de alteração verificada nos feldspatos (sericitização). 
O Falésia apresentou, comparativamente, os maiores valores de dilatação térmica dentre as três rochas estudadas. A quantidade mais expressiva de biotita neste litotipo favorece a dilatação, uma vez que a biotita é mais susceptível à fadiga térmica, incorrendo no alargamento de linhas de clivagem e podendo conduzir ao destacamento generalizado nas superficies de clivagem.

As três amostras se comportam como rochas de média a alta condutividade térmica com valores médios de $3,19 \mathrm{~W} / \mathrm{m}^{\circ} \mathrm{K}$ para o Casablanca e $3,64 \mathrm{~W} / \mathrm{m}^{\circ} \mathrm{K}$ para o Delicato. O Falésia apresenta o menor valor médio que é de $2,99 \mathrm{~W} / \mathrm{m}^{\circ} \mathrm{K}$, sendo este resultado creditado à ocorrência de microfissuras e à maior intensidade de alteração dos minerais que compõem esta rocha.

Os resultados de condutividade térmica ratificaram e responderam de forma coerente a todos os demais ensaios físicos e tecnológicos, na medida em que apontaram resultados mais elevados para o Delicato e mais baixos para o Falésia, sugerindo ser esta mais uma ferramenta eficaz na caracterização petrofísica das rochas. Este ensaio possui a vantagem de ser um método não destrutivo, de execução rápida e de baixo custo.
Estes resultados são igualmente importantes na ampliação do conhecimento acerca da abrangência desta variável (condutividade térmica) mediante processos de transferência de calor, especialmente nos segmentos da construção civil e da indústria de rochas ornamentais. São úteis na medida em que mostram o comportamento da condutividade térmica a partir das principais variáveis envolvidas (mineralogia, textura, etc.), fornecendo dados mais precisos dos variados materiais que irão proporcionar a realização de cálculos de maior exatidão de conforto térmico em edificações, dilatação térmica linear de revestimentos, comportamento de rochas mediante extração com jet flame, beneficiamento do tipo flameado etc.

Agradecimentos Os autores agradecem ao Conselho Nacional de Desenvolvimento Científico e Tecnológico (CNPq), pela concessão de uma bolsa de doutoramento ao primeiro autor e financiamento da pesquisa. Ao laboratório de Condutividade Térmica da Universidade Federal do Rio Grande do Norte-UFRN, pela obtenção dos dados de condutividade térmica.

\section{Referências}

ASSOCIAÇÃO BRASILEIRA DE NORMAS TÉCNICAS (ABNT). (1992a) NBR 12768/92: Rochas para revestimento - análise petrográfica. Rio de Janeiro.

(1992b) NBR 12766/92: Rochas para revestimento - determinação da massa específica aparente, porosidade aparente e absorção d'água aparente. Rio de Janeiro.

(1992c) NBR 12767/92: Rochas para revestimento - Determinação da resistência à compressão uniaxial. Rio de Janeiro.

(1992e) NBR 12765/92: Rochas para revestimento - Determinação do coeficiente de dilatação térmica linear. Rio de Janeiro.

AMERICAN SOCIETY FOR TESTING AND MATERIALS (ASTM). (2000) D 2845/00: standard method for laboratory determination of pulse velocities and ultrasonic elastic constants of rocks. Philadelphia.

Navarro F.C. 1998. Granitos ornamentais: análise petrográfica na previsão do comportamento físico-mecânico. In: Congresso Uruguayo de Geologia, 2, Montevideo, $A c$ tas, p. 103.

Rodrigues E.P., Chiodi Filho C., Coutinho J.M.V. 1997. Importância da petrografia para a previsão do comportamento e da durabilidade de rochas ornamentais. Lisboa: Rochas e Equipamentos, 47:12-15.

Rodrigues E.P., Coutinho J.M.V., Chiodi Filho C. 1996. Petrografia microscópica: uma visão do passado, presente e futuro da rocha ornamental. Rochas de Qualidade, 127:80-84.

Artur A.C., Meyer A.P., Wernick E. 2001. E. Características tecnológicas de granitos ornamentais: a influência da mineralogia, textura e estrutura da rocha. Dados comparativos e implicações de utilização. In: Museu Geológico da
Bahia, Simpósio Brasileiro de Rochas Ornamentais, 1, Seminário de Rochas Ornamentais do Nordeste, 2, Salvador, Anais, p. 13.

Navarro F.C. Velocidade de propagação de ondas ultra-sônicas como ferramenta para a previsão de parâmetros mecânicos em granitos ornamentais. 2002. In: CETEM, Simpósio de Rochas Ornamentais, 3, Rio de Janeiro, Anais, 1:20.

Navarro, F.C.; Artur, A.C. 2002. Caracterização petrográfica como uma ferramenta para a previsão do comportamento físico e mecânico de granitos ornamentais: uma discussão. In: CETEM, Simpósio de Rochas Ornamentais, 3, Rio de Janeiro, Anais, 1:2.

Lima J.J.C. 2002. Estudo da dilatação térmica de rochas usadas em revestimento de edificações. Dissertação de Mestrado, Escola de Engenharia de São Carlos, Universidade de São Paulo, 121 p.

Frazão E.B., Farjallat J.E. 1995. Características tecnológicas das principais rochas silicáticas brasileiras usadas como pedras de revestimento. In: Congresso Internacional da Pedra Natural, 1, Lisboa, Anais, p. 47.

Frazão E.B. 2002. Tecnologia de rochas na construção civil. São Paulo: Associação Brasileira de Geologia de Engenharia e Ambiental-ABGE, $132 \mathrm{p}$.

Frascá M.H.B.O. 2003. Estudos experimentais de alteração acelerada em rochas graníticas para revestimento. Tese de Doutoramento, Instituto de Geociências, Universidade de São Paulo, 264 p.

Manuscrito ID 14580

Submetido em 16 de junho de 2009 Aceito em 04 de março de 2010 